\title{
Lactococcus lactis Suşlarının Stres Koşullarına Dirençlilik Özellikleri"
}

\author{
Rahmi LALE ${ }^{1} \quad$ Mustafa AKÇELIK ${ }^{2}$
}

Geliş Tarihi : 29.12.2003

\begin{abstract}
Özet: Bu çalişmada, L. lactis subsp. lactis LL52, L. lactis subsp. cremoris LC79 ve L. lactis subsp. lactis biovar. diacetylactis LD62 suşlarında dört farklı stres koşuluna karş̧ hücresel dirençlilik gelişimi araştıııldı. Stres koşulu olarak yüksek ve düşük sıcaklık, düşük asitlik ve ozmotik basıncın kullanıldığı denemelerde, LL52 diğer sușlardan daha duyarlı bulundu. Stres koşullarına dirençlilik ya indüksiyona bağlı ya da sürekli bir karakter gösterdi. Stres dirençlilik indüksiyonu, bakteri tipine ve stres faktörlerine bağlı olarak hücre üremesinin 40 ve 90 dakikaları arasında meydana geldi,
\end{abstract}

Anahtar Kelimeler: Lactococcus lactis, stres, direnç

\section{Resistance Characteristics of Lactococcus lactis Strains Under Stress Conditions}

Abstract: In this study, cellular resistance responses against four stress factors were investigated for the strains L. lactis subsp. lactis LL52, L. lactis subsp. cremoris LC79 and L. lactis subsp, lactis biovar. diacetylactis LD62. Strain LL52 was found to be the most sensitive strain at the end of stress bioassays such as high and low temperatures, low $\mathrm{pH}$ and osmotic pressure. Stress resistance specificities of these strains were showed either inducible or constitutive characteristics. Stress resistance induction occurred between $40-90$ minutes of cell growth according to the bacterial types and stress factors.

Key Words: Lactococcus lactis, stress, resistance

\section{Giriş}

Laktokokların (Lactococcus) starter kültür olarak kullanılan suşları; fermente süt ürünlerinin yapısal ve aromatik özelliklerinin gelişimi yanında, bu ürünlerin gıda kökenli hastalık ya da gıda bozulması etmeni bakterilerden korunmasında da aktif bir rol oynamaktadır (Schleifer ve ark. 1985, Kim ve ark. 1999). Starter kültürler, taşınma, saklama, kültür transferi ve endüstriyel fermentasyonların değişik aşamalarında stres koşullarına maruz kalmaktadır. Bunların başıcaları; hammadde işleme süreçlerinde tipik stres koşulu olan yüksek sıcaklık, üretilen starter kültür preparatlarının saklanmasında karşılaşılan düşük sıcaklık ya da ozmotik basınç (sprey kurutucularda kurutma işlemine bağlı olarak ortaya çıkar) ve çoğu kez doğal ortamlarında güneş altında maruz kalınan ultraviyole ışınlar (yüksek sıcaklık ile birlikte), olarak sayılabilir (Le Bourgeois ve ark. 1995, Sanders ve ark. 1999). Doğal koşullarda kritik bir diğer stres faktörü de yetersiz besin arzıdır (Duwat ve ark. 1999). Üreme yeteneğindeki hücre sayısında önemli ölçüde düşmeye yol açan stres koşullarına dirençli starter kültür suşlarının seçimi ve kullanımi, fermente gıda üretiminde kalite ve maliyet ekonomisi açısından büyük önem taşımaktadır. Dirençli suşların seçiminde stres koşullarının tanımlanması en kritik aşamayı teşkil etmektedir.

"Yüksek Lisans Tezinden hazırlanmıştır.

${ }^{1}$ Department of Biochemistry, NTNU University, Torndhaim-Norway

${ }^{2}$ Ankara Üniv. Fen Fak. Biyoloji Bölümü-Ankara
Zira, doğal ekosistemlerin önemli ölçüde zarar gördüğü günümüz dünyasında, herhangi bir organizma için optimum koşullardan söz etmek ancak deneysel ortamlarda mümkün olmaktadır (Fukuda ve ark. 2002, Kleerebezem ve ark. 2002, Weber ve Jung 2002). Özetle doğal koşullarda yaşamın sürekliliği, organizmaların karşı karşıya kaldıkları stres koşullarına adaptasyon yetenekleri ile doğrudan ilişkili hale gelmiştir (Jakob ve ark. 1999).

Bu araştırmada; yüksek ve düşük sıcaklık, düşük asitlik ve ozmotik basınç gibi dört değișik stres koșuluna karşı direnç yanıtı oluşturan Lactococcus lactis suşlarının tanımlanması amaçlanmıştır.

\section{Materyal ve Yöntem}

Calışma kapsamında kullanılan, $L$. lactis subsp. lactis LL52, L. lactis subsp. cremoris LC79 ve L. lactis subsp. lactis biovar. diacetylactis LD62 suşları Ankara Üniversitesi Ziraat Fakültesi Gıda Mühendisliği Bölümü kültür koleksiyonundan sağlanmıştır. Suşlar M17 broth ortamlarında (Terzaghi ve Sandine 1975) $30^{\circ} \mathrm{C}$ 'de 12 saat süreyle geliştirilmiş ve haftalık transferler yapılarak $+4^{\circ} \mathrm{C}$ 'de muhafaza edilmiștir. 


\section{Bakterilere stres koşullarının uygulanması}

M17 sıVı besiyerinde $30^{\circ} \mathrm{C}^{\prime}$ de 18 saat süreyle geliştirilen kültürler steril santrifüj tüplerine aktarılmış ve $5500 \mathrm{devir} / \mathrm{dk}$ hızda $15 \mathrm{dk}$ santrifüj işlemine tabi tutularak çöktürülmüştür. Deneyden bir saat önce $42^{\circ} C^{\prime}$ ye ayarlı su banyosuna konulan GM17 sıvı besiyeri içerisinde bakteri çökeltileri çözülmüş ve hücre süspansiyonları $42^{\circ} \mathrm{C}$ 'deki su banyosunda 10 - $150 \mathrm{dk}$ süreyle inkübasyona bırakılarak yüksek sıcaklık uygulaması yapılmıştır. Örnekler her 10 dk'da bir alınarak analiz edilmiştir (Whitaker ve Batt 1991). Aynı koşullarda hazırlanan ve örneklenen L. Lactis suşlarında ; düşük sıcaklık stres koşulu için $+8^{\circ} \mathrm{C}$ inkübasyon sıcaklığı, ozmotik basınç stres koşulu için \% 2.5 tuz ( $\mathrm{NaCl})$ konsantrasyonu içeren gelişme ortamı ve düşük asitlik stres koşulu için de $\mathrm{pH}$ $5.5^{\prime}$ e ayarlanan gelişme ortamı kullanılmıştır (Wouters ve ark. 1998; Wouters ve ark. 1999, Guillot ve ark. 2000, Kim ve ark. 2002).

Canlı koloni sayımı sonucu elde edilen tablo girdileri, faktöryel varyans analizi ile değerlendirilmiştir (Norman 1981).

\section{Bulgular ve Tartışma}

Stres uygulamalarından toplam etkilenme düzeylerinin bakteri türleri ile ilişkisinin bulunup bulunmadığı, çoklu karşılaştırma testi kullanılarak ölçülmüştür. Bu test sonucunda L. lactis subsp. lactis LL52 suşunun stres koşullarından diğer iki bakteriye oranla daha yüksek düzeyde etkilendiği $(-2,044)$, L. lactis subsp. lactis biovar. diacetylactis LD62 ile L. lactis subsp. cremoris LC79 suşları arasında ise anlamlı bir üreme farklılığının meydana gelmediği belirlenmiştir (Çizelge 1).

LL52 Yüksek Sıcaklık

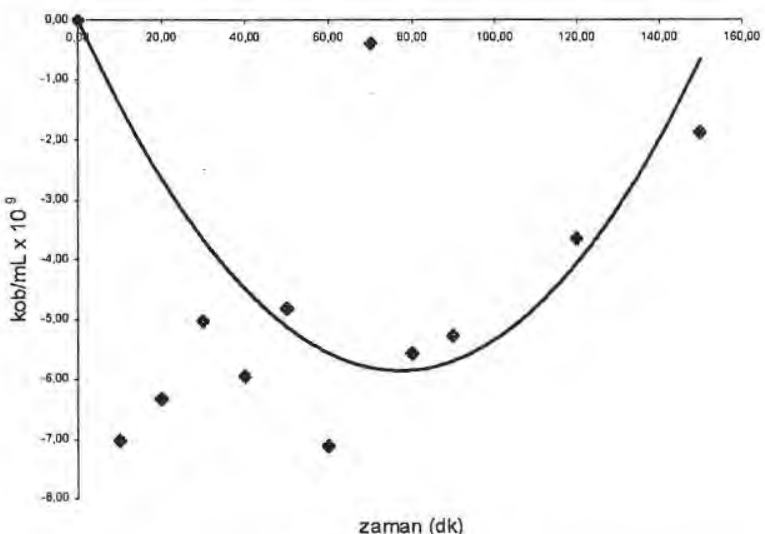

Şekil 1. L. lactis subsp. lactis suşunun yüksek sıcaklık stresi altındaki gelişim eğrisi
Bakterilerin stres koşulları altında, zamana karşı üreme grafikleri Şekil $1,2,3,4,5,6,7,8,9,10,11$ ve 12 'de verilmiştir. L. lactis subsp. lactis LL52 suşunda, yüksek sıcaklık uygulamasının $0-80 \mathrm{dk}$ 'ları arasında canlı hücre sayısında düşme belirlenmiştir. 80 . dk'dan sonra, stres koşuluna geliştirilen hücresel yanıta bağlı olarak, 150. dk'ya kadar sürekli artış meydana gelmiştir (Şekil 1). Yüksek sıcaklık stresi altında $L$. lactis subsp. lactis biovar. diacetylactis LD62 suşunda, L. lactis subsp. lactis LL52 suşunun tam aksine, 80 . dk'ya kadar üremede artış olmuş, 80 - 150 dk'ları arasında, hücresel stres yanıtının geliştirilememesi nedeni ile sürekli azalma tespit edilmiştir (Şekil 2). L. lactis subsp. cremoris LC79 suşunda da sıcaklık stresine karşı hücresel yanıt geliştirilememiştir. $L$. lactis subsp. lactis biovar. diacetylactis LD62 suşu ile benzer bir şekilde, bu suşta da stres uygulamasının 50 . dk'sına kadar canlı hücre sayısı artmış, 50 - 150 dk'ları arasında azalmıştır (Şekil 3).

Düşük sıcaklık stresine karşı, her üç bakteri de benzer sonuçlar meydana gelmiştir. Stres koşulu uygulamasında $L$. lactis subsp. lactis LL52 ve L. lactis subsp. cremoris LC79 suşlarında 70 . dk, L. lactis subsp. lactis biovar. diacetylactis LD62 suşunda ise 80 . dk'ya kadar canlı hücre sayısı azalmış, bu sürelerden sonra, stres yanıtına bağlı olarak, üremede artış başlamıştır (Şekil 4, 5 ve 6).

Çizelge 1. L. lactis suşlarının stres faktörlerinden toplam etkilenme düzeyleri

\begin{tabular}{llll}
\hline Bakteri & LLLL52 & LDLD622 & LCLC79 \\
\hline Ortalama & $-2,044^{A^{*}}$ & $1,139^{B}$ & $0,315^{B}$
\end{tabular}

* Aynı üst simgeler farklanma olmadığını, farklı üst simgeler farklanma olduğunu gösterir.

LD62 Yüksek Sicaklık

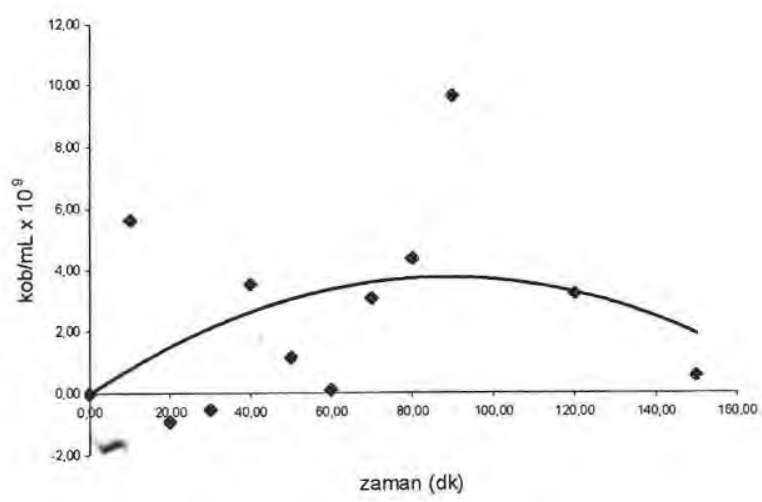

Şekil 2. L. lactis subsp. lactis biovar. diacetylactis LD62 suşunun yüksek sıcaklık stresi altındaki gelişim eğrisi 
LC79 Yüksek Sıcaklık

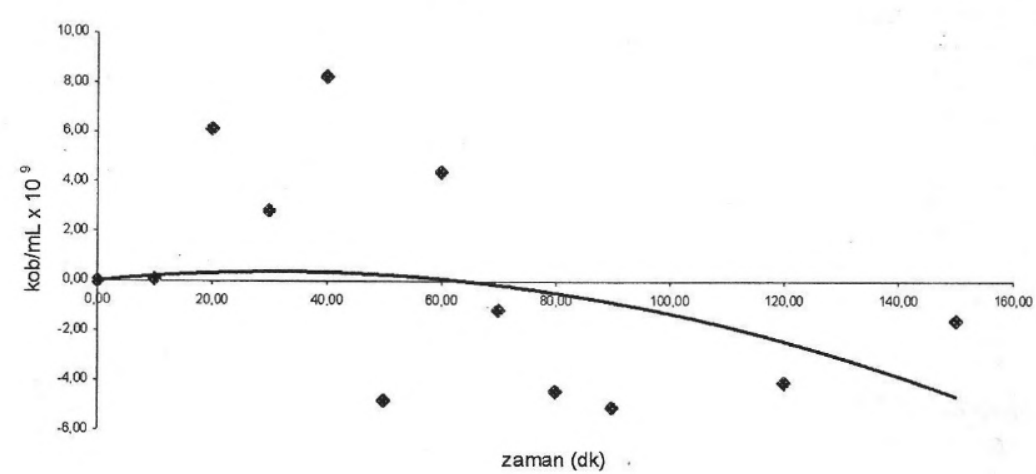

Şekil 3. L. lactis subsp. cremoris LC79 suşunun yüksek sıcaklık stresi altındaki gelişim eğrisi

LD62 Düşük Sıcaklık

LL52 Düşük Sıcaklık

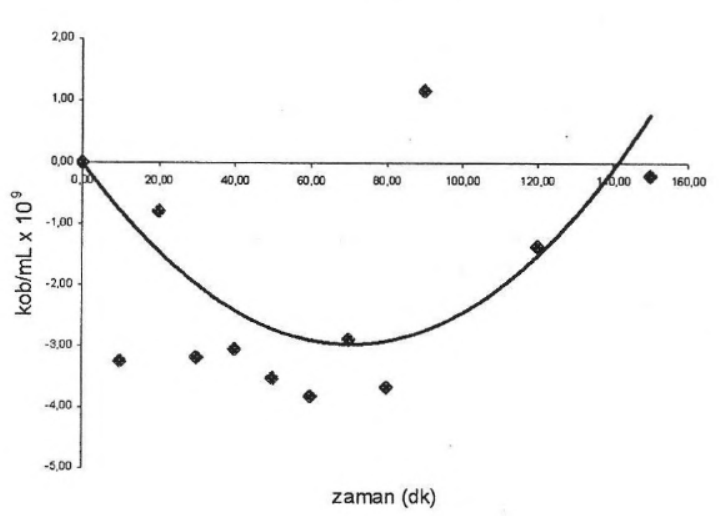

Şekil 4. L. lactis subsp. lactis LL52 suşunun düşük sıcaklık stresi altındaki gelişim

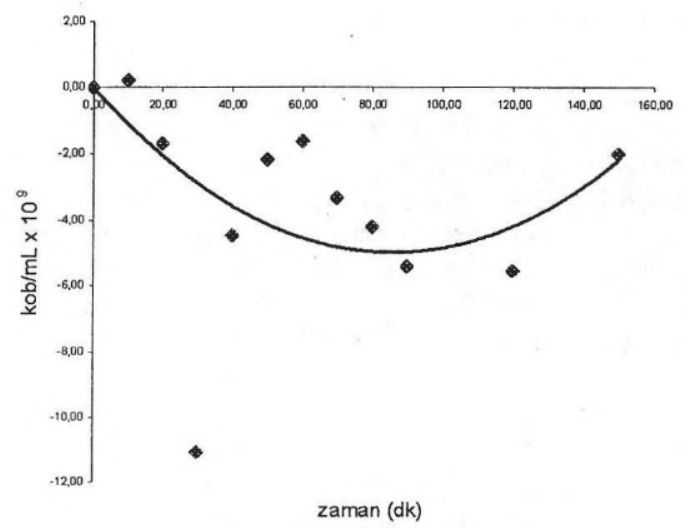

Şekil 5. L. lactis subsp. lactis biovar. diacetylactis LD62 suşunun düşük sıcaklık stresi eğrisi altındaki gelişim eğrisi

LC79 Düşük Sıcaklık

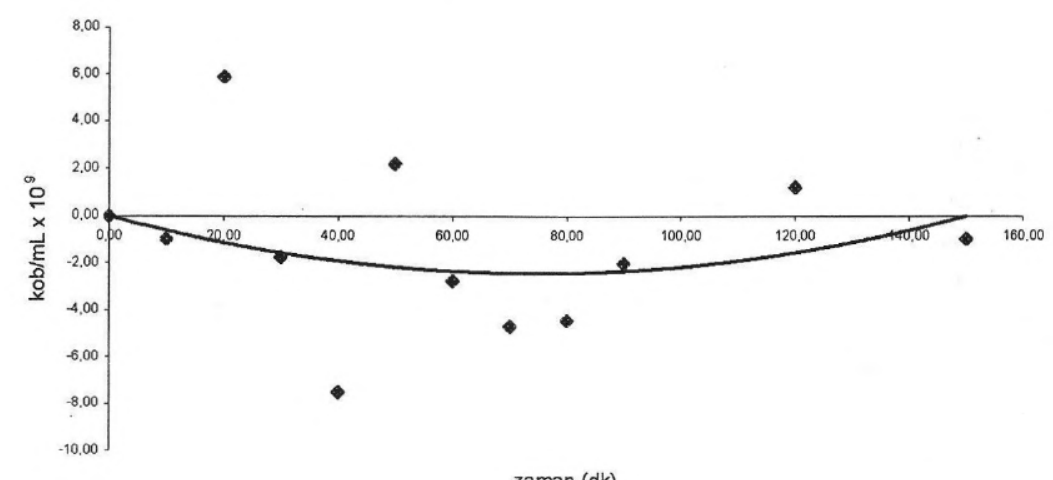

zaman (dk)

Şekil 6. L. lactis subsp. cremoris LC79 suşunun düşük sıcaklık stresi altındaki gelişim eğrisi 
Ozmotik stres koşullarında $L$. lactis subsp. lactis LL52 suşunda hücresel yanıt hazırlık süresi $0-40 \mathrm{dk}$ arasında tanımlanmıştır. Bu zaman diliminde üremede azalma meydana gelirken, $40-150 \mathrm{dk}$ arasında, stres koşullarına direnç özelliğinin kazanılması sonucu, artış belirlenmiştir (Şekil 7). L. lactis subsp. lactis biovar. diacetylactis LD62 sușu ozmotik stres altında sürekli artan bir üreme karakteristiği göstermiştir (Şekil 8). Bu bulgu, söz konusu suşun ozmotik stres koşuluna uyum için sürekli üretilen yanıt mekanizmaları içerdiğine işaret etmektedir.

L. lactis subsp. cremoris LC79 suşu ise ozmotik şok koşullarına 60. dk'dan sonra stres yanıtı oluşturmuştur. Zira üremede artış bu süreden sonra başlamıştır (Şekil 9). Düşük asitlik stresi altında L. lactis subsp. lactis LL52 suşunun üremesinde 90 . dk'ya kadar azalma saptanırken, 90 - 150 dakikaları arasında sürekli bir artış gözlenmiştir (Şekil 10). Bu bulgu; L. lactis subsp. lactis LL52 suşunun, söz konusu stres koşuluna karşı hücresel yanıt oluşturabilmek için $90 \mathrm{dk}$.'lık bir hazılık süresine intiyaç duyduğunu ispat etmektedir.

L. lactis subsp. lactis biovar. diacetylactis LD62 suşunda 80 . dk'ya kadar artan canlı hücre sayısı, 80 - 150 dakikaları arasında azalmıştır (Şekil 11). L. lactis subsp. cremoris LC79 suşu ise, düşük asitlik koşullarında sürekli artan bir üreme karakteristiği göstermiştir (Şekil 12). Bu bulgu da, L. lactis subsp. cremoris LC79 suşunun düşük asitlik koşullarında geliştirdiği hücresel yanıt mekanizmalarının süreklilik arz ettiğini kanıtlamaktadır .

Literatür verilerinde genellikle $L$. lactis subsp. lactis'in stres koşullarına karşı L. lactis subsp. cremoris'ten daha dirençli olduğu belirtilmektedir (Duwat ve ark.1999, Sanders ve ark.1999, Pillidge ve ark. 2002, Frees ve ark. 2003). Türkiye kökenli L. lactis suşlarında bu literatür verilerinin aksine stres faktörlerinin toplam etkinliğine karşı en hassas suş $L$. lactis subsp. lactis LL52 olarak belirlenmiştir. LL52 suşu, denenen tüm stres faktörlerine karşı stres direnç yanıtı oluşturma özelliği ile de LD62 ve LC79 suşlarından ayrılmıştır. Bu farklı karakteristikleri LL52 suşunu gerek bilimsel ve gerekse endüstriyel açıdan önemli hale getirmektedir. Diğer yandan ozmotik stres yanıtının $L$. lactis'te genellikle yüksek sıcaklık stresi ile benzer mekanizmalar içerdiğine dair literatür verileri de (Sanders ve ark. 1999, Vereecken ve Van Impe 2002, Frees ve ark. 2003) araştırmamızda kullanılan LD62 ve LC79 suşlardan elde edilen bulgular ile uyumlu değildir. Zira, LD62 ve LC79 suşlarında ozmotik strese karşı yanıt geliştirilmiş ancak yüksek sıcaklık stresine başlangıçta direnç göstermelerine rağmen, süreklilik arz eden bir yanıt oluşturulamamıştır. Bu suşlarda hücresel stres yanit mekanizmalarının detaylı bir şekilde çalışııması, L. lactis'te biyokimyasal ve genetik farklılaşmanın esasına ilişkin ipuçları sunabilir.

Stres koşullarına karşı Türkiye kökenli $L$. lactis suşlarında, genel bakteriyel yanit sistemlerinde de olduğu gibi, ya belirli bir düzeyde direnç gösterildikten sonra yanıtı oluşturacak proteinlerin ileri düzeyde indüksiyonu gerçekleştirilememiş (yüksek sıcaklık stresine karşı LC79 ve LD62 suşlarının yanıtında olduğu gibi) ya da bakterinin sürekli dirençliliğini sağlayacak yanıt oluşturulmuştur. Starter kültür suşlarında tercih edilen stres direnç mekanizmaları, süreklilik arz eden yanıt sistemleridir. Zira, endüstriyel fermentasyonlarda belirli bir stres faktörü ya da stres faktörlerinin birkaçı bir arada bulunabilir ve uzun süreli etkinlik gösterebilirler. Diğer yandan, laktokokların alternatif kullanım alanı olan gastrointestinal sisteme aşı taşınımı, ancak bu organizmaların düşük asit stresine stabil bir şekilde direnç gösteren suşları ile mümkün olabilir (Sanders ve ark. 1999, Kim ve ark. 2001).

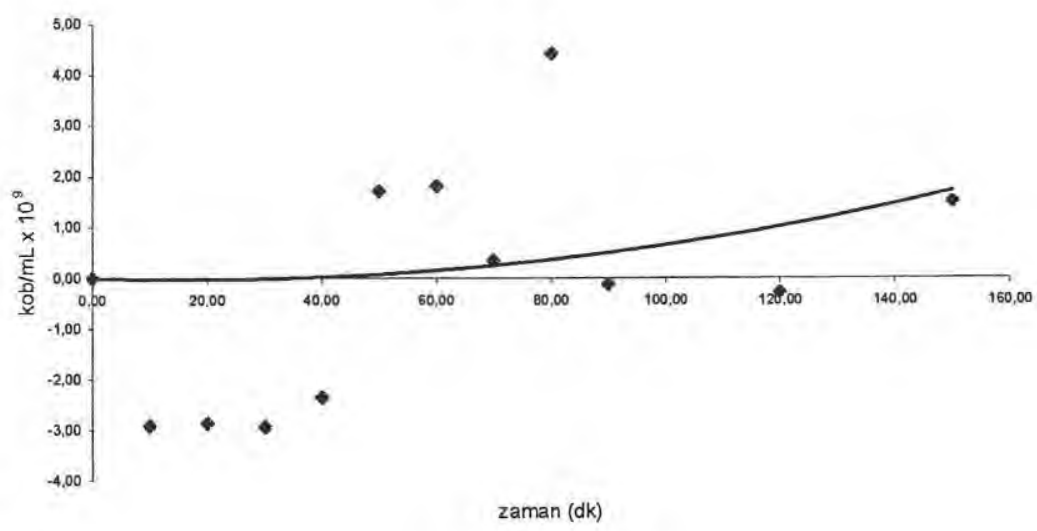

Şekil 7. L. lactis subsp. lactis LL52 suşunun ozmotik stres altındaki gelişim eğrisi 
.LD62 Ozmotik Şok

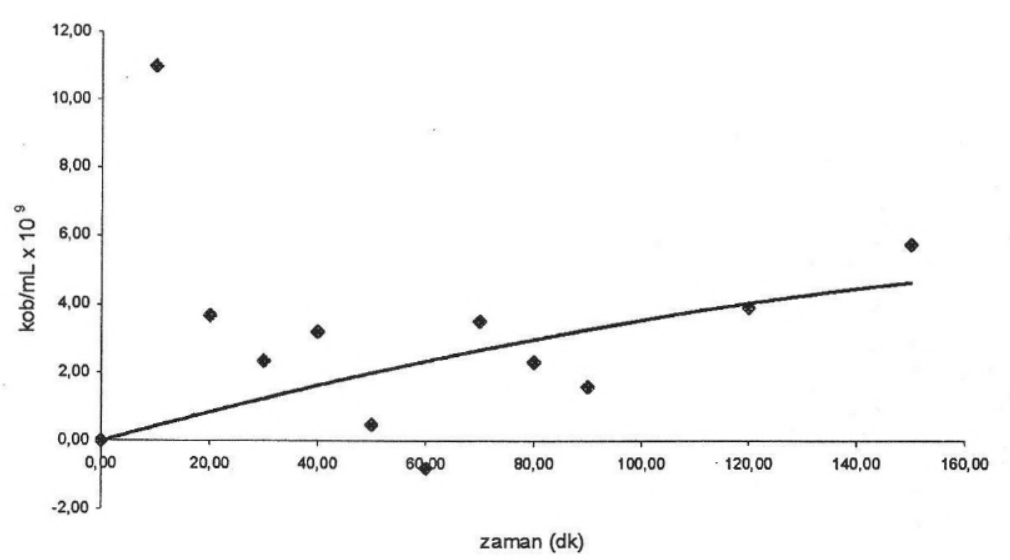

Şekil 8. L. lactis subsp. lactis biovar. diacetylactis LD62 suşunun ozmotik stres altındaki gelişim eğrisi

LC79 Ozmotik Şok

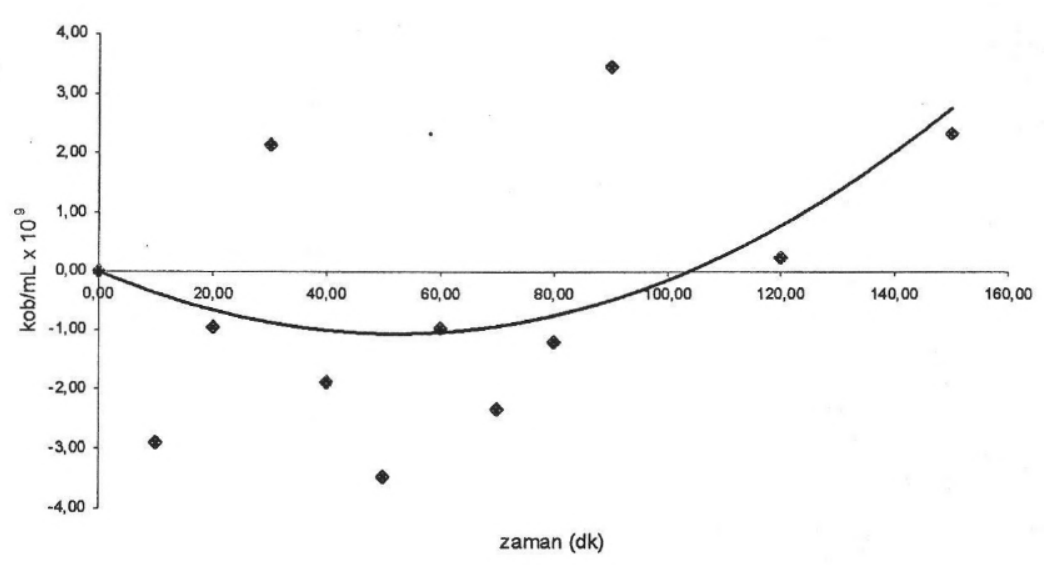

Şekil 9. L. lactis subsp. cremoris LC79 suşunun ozmotik stres altındaki gelişim eğrisi

u 52 Duşuk Astilk

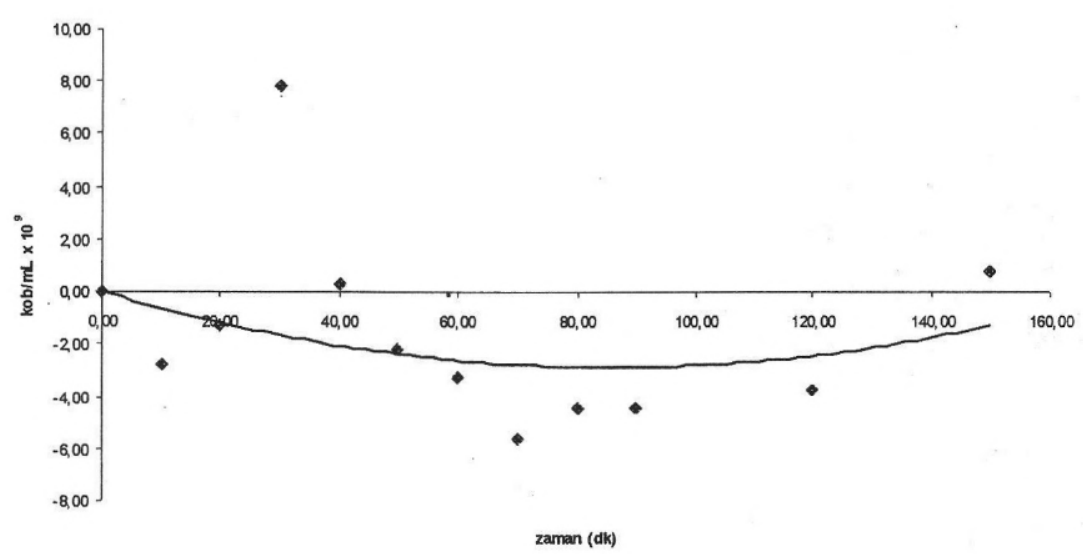

Şekil 10. L. lactis subsp. lactis LL52 suşunun düşük asitlik stresi altındaki gelişim eğrisi 
LD62 Düșük Asitlik

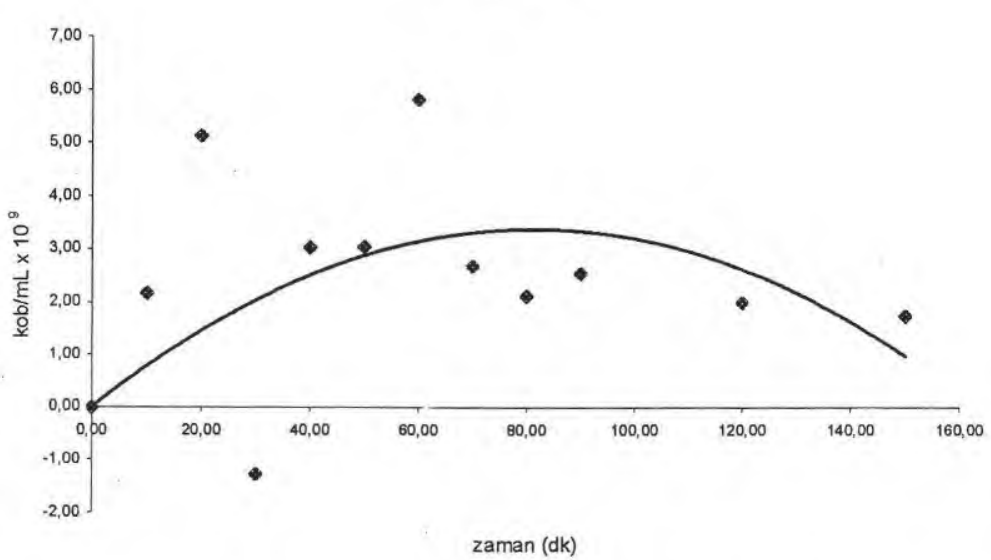

Şekil 11. L. lactis subsp. lactis biovar. diacetylactis LD62 suşunun düşük asitlik stresi altındaki gelişim eğrisi

LC79 Düşük Asitlik

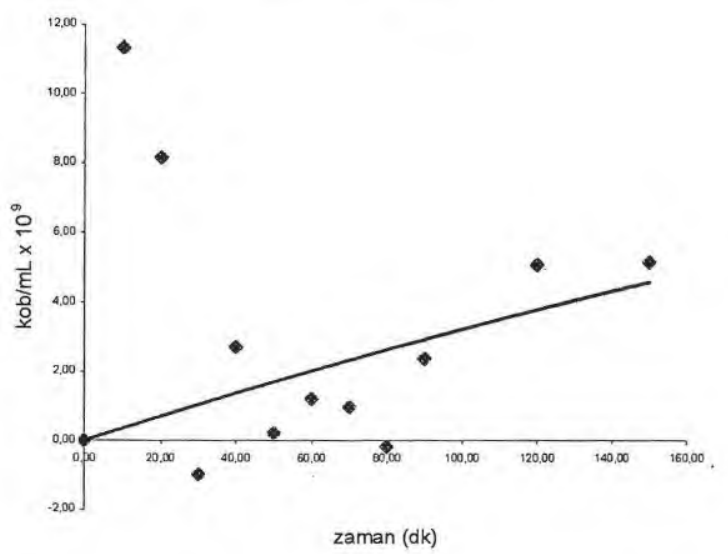

Şekil 12. L. lactis subsp. cremoris LC79 suşunun düşük asitlik stresi altındaki gelişim eğrisi

LC79 ve LD62 suşlarında olduğu gibi, yüksek sıcaklık stresine belirli düzeyde ve sürede direnç gösterebildikten sonra, bu direncin kırılarak hücrelerin parçalanması da, özellikle peynir endüstrisi açısından kritik öneme sahip bir bulgudur. Peynirin olgunlaşması ve aromasının oluşumu, süt proteinlerinin aşamalı parçalanması ile elde edilmektedir. L. lactis, bu proteinlerin parçalanması için hücre içi ve hücre dışı proteinaz sistemlerini kullanmaktadır. Peynirin olgunlaşması üzerine yapılan çalışmalar, aroma ve tat oluşumunda rol alan ana enzim grubunun hücre içi peptidazlar olduğunu göstermiştir (Bie ve Sjostrom 1975, Ardo ve Pettersson 1988, Allison ve Klaenhammer, 1998, Pillidge ve ark. 2002). Peynir fermentasyonlarında olgunlaşmanın hızlandırıması amacı ile kullanılan temel yöntem, fermentasyonun ileri aşamalarında ısı şoku uygulaması ile bakteriyel parçalanmanın sağlanmasıdır (Ardo ve Pettersson 1988, Wood ve ark. 2001). Bu açıdan bakıldığında LC79 ve LD62 suşlarındaki ısıl direncin belirli bir zaman sonunda kırılması, starter kültür suşlarında indüklenen liziz için model sistem olarak kullanılabilecek nitelik taşımaktadır.

\section{Sonuç}

Türkiye kökenli L. Lactis suşlarının, endüstriye üretim koşullarında en fazla rastlanılan stres faktörlerine karşı oluşturduğu direnç yanıt özellikleri, bu bakterilerin starter kültür suşları ve vektör sistemler olarak kullanımlarında referans oluşturacak niteliktedir. Özellikle denenen tüm stres faktörlerine direnç oluşturan LL52 suşu, endüstriyel potansiyeli açısından öne çıkmaktadır. Diğer yandan LC79 ve LD62 suşlarının sıcaklık stresine karşı sürekli bir direnç yanıtı geliştirememeleri, peynir üretiminde ekonomik yönden kritik bir önem taşıyan olgunlaştırma sürecinin kısaltılması uygulamasını mümkün kılacaktır. Bunlara ilave olarak, Türkiye kökenli bakterilerin, benzer stres koşulları altında, literatür verilerinde tanımlanan starter kültür suşlarına göre bazı farklı yanıt mekanizmalarına sahip olması, bu bakterilerin bilimsel araştırmalarda model sistemler olarak kullanımını beraberinde getirecektir.

\section{Teşekkür}

Istatistiki analizler konusunda yaptığı katkılardan dolayı Sayın Doç. Dr. Ensar BAŞPINAR'a (Ankara Üniversitesi, Ziraat Fakültesi, Hayvansal Üretim Bölümü, Genetik ve Istatistik Birimi) teşekkür ederiz. 


\section{Kaynaklar}

Allison, G. E. and T. R. Klaenhammer, 1998. Phage resistance mechanisms in lactic acid bacteria. Int. Dairy J., $8,207-226$

Ardo, $Y$, and $H$. E. Pettersson, 1998. Accelerated cheese ripening with heat treated cells of Lactobacillus helveticus and a commercial proteolytic enzyme. J. Dairy Res., 55, 239-246.

Bie, R. and G. Sjostrom, 1975. Autolytic properties of some lactic acid bacteria used in cheese production. Part II. Experiments with fluid substrate and cheese. Milchwissenschaft, 30, 739747.

Duwat, P., S. D. Erlich and A. Grus, 1999. The recA gene of Lactococcus lactis: characterization and involvement in oxidative and thermal stress. Mol. Microbiol., 17, 1121-1131.

Frees, D., F. K. Vogensen and H. Ingmer, 2003. Identification of proteins induced at low pH in Lactococcus lactis. Int. J. Food Microbiol. (In press).

Fukuda, D., M. Watanabe, S. Sonezaki, S. Sugimoto, K Sonomoto, and A. Ishizaki, 2002. Molecular characterization and regulatory analysis of dnaK operon of halophilic lactic acid bacterium Tetragonococcus halophila. J. Biosci. Bioeng., 93, 88-394.

Guillot, A., D. Obis and M. Y. Mistou, 2000. Fatty acid membrane composition and activation of glycine-betaine transport in Lactococcus lactis subjected to osmotic stress. Int. J. Food Microbiol., 55, 47-51.

Jakob, U., W. Muse, M. Eser and J. C. A. Bardwell, 1999. Chapoerone activity with redox switch. Cell, 96, 314-352.

Kim, W. S., J. Ren and N. W. Dunn, 1999. Differentiation of Lactococcus lactis subspecies lactis and subspecies cremoris strains by their response to stresses. FEMS Microbiol. Let., 171, 57-65.

Kim, W. S., J. H. Park, J. Ren, P. Su and N. W. Dunn, 2001 Survival response and rearrangement of plasmid DNA of Lactococcus lactis during long-term starvation. Appl. Environ. Microbiol., 67, 4594-4602.

Kim, W. S., J. H. Park, J. E. Tandianus, J. Ren, P. Su and N. W. Dunn, 2002. A distinct physiological state of Lactococcus lactis cell that confers survival against a direct and prolonged exposure to severe stresses. FEMS Microbiol. Let, 212, 203208

Kleerebezem, M., I. C. Boels, M. N. Groot, I. Mireau, W. Sysbesma and J. Hugenholtz, 2002. Metabolic engineering of Lactococcus lactis: the impact of genomics and metabolic engineering. J. Biotech., 98, 99-213.

Le Bourgeois, P., M. Lautier, L. Van Den Berghe, M. J. Gasson and P. Ritzenthaler, 1995. Physical and genetic map of the Lactococcus lactis subsp. cremoris MG1363 chromosome. J. Bacteriol., 177, 2840-2850.
Norman, T. J. B. 1981. Statistical methods in Biology. Edward Arnold, Chapman and Hall, Inc., 269 p., New York.

Pillidge, C. J., P. S. Rallabhandi, X. Tong, P. Gopal, P. C Farley and P. A. Sullivan, 2002. Autolysis of Lactococcus lactis. Int. Dairy. J., 12, 133-140,

Sanders, J. W., G. Venema, and J. Kok, 1999. Environmental stress response in Lactococcus lactis. FEMS Microbiol. Rev., 23, 483-501.

Schleifer, K. H., J. Kraus, G. Drovak, R. Klipper-Balz, M. D. Collins and W. Fischer, 1985. Transfer of Streptococcus lactis and related streptococci to the genus Lactococcus gen. nov. Syst. Appl. Microbiol., 6, 183-195.

Terzaghi, B. E. and W. Sandine, 1975. Improved medium for lactic streptococci and their bacteriophages. Appl. Environ. Microbiol., 29, 807-813.

Vereecken, K. M. and J. F. Van Impe, 2002. Analysis and practical implemetation of a model for combined growth anc metabolite production of lactic acid bacteria. Int. J. Food Microbiol., 73, 239-250.

Weber, A. and K. Jung, 2002. Profiling early osmostressdependent gene expression in Escherichia coli using DNA macroarrays. J. Bacteriol., 184, 5502-5507.

Whitaker, R. D. and C. A. Batt, 1991. Characterization of the heat shock response in Lactococcus lactis subsp. lactis. Appl. Environ. Microbiol., 57, 1408-1412.

Wood, J. M., E. Bremer, L. N. Csonka, R. Kraemer, B. Poolman and L. T. Smith, 2001. Osmosensing and osmoregulatory compatible solute accumulation by bacteria. Com. Biochem. Physiol. Part A, 130, 437-460.

Wouters, J. A., J. W. Sanders, J. Kok, W. M. De Vos, O. P. Kuipers and T. Abee, 1998. Clustered organization and transcriptional analysis of a family of five csp genes of Lactococcus lactis MG1363. Microbiol., 144, 2885-2893.

Wouters, J. A., B. Jeynoy, F. M. Rombouts, W. M. De Vos, O. P. Kuipers and T. Abee, 1999. Analysis of the role of $7 \mathrm{kDa}$ cold-shock proteins of Lactococcus lactis MG1363 in cryoprotection. Microbiology, 145, 3185-3194.

\section{İletişim Adresi:}

\section{Mustafa AKÇELIK}

Ankara Üniversitesi, Fen Fakültesi Biyoloji Bölümü - Ankara Fax: 3123178711

E-mail: akcelik@science.ankara.edu.tr 